\title{
The Acceleration of Digital Transformation in the Ministry of Finance: What Are the Driven Factors?
}

\author{
Ganjar Asdi Sudrajat \\ Faculty of Social and Political Sciences, Universitas Airlangga (email: ganjar.asdi.su-2020@fisip.unair.ac.id)
}

\begin{abstract}
The development of technology, communication, and information has had a major impact and has also changed people's perceptions of public services. People want public services that are fast, transparent, accountable, and accessible. Digital transformation is an effort made by the government to meet people's expectations for public services. The Ministry of Finance is one of the institutions that has been able to implement digital transformation programs in the public sector. The digital transformation program carried out allows the Ministry of Finance to quickly adapt to new habits at work during the Covid-19 pandemic to maintain the continuity of the organization's tasks. This study aims to determine the various factors that support the implementation of the digital transformation program at the Ministry of Finance. The study used a descriptive method with a qualitative approach. The data was obtained through a literature study by examining various literatures related to the Ministry of Finance's digital transformation program. The results of the study show that the digital transformation program at the Ministry of Finance is strongly supported by the commitment and full support of the leader, resources (infrastructure, system, human resources, and regulations), and employee engagement.
\end{abstract}

\section{Keywords:}

digital transformation; technology; information

\section{Introduction}

The massive development of information and technology has a major impact on human life. Technology has changed the perspective of individuals in viewing the world about how they live and relate to others (Chi et al., 2017). As an illustration, the existence of smartphone technology that provides various features has replaced the existence of conventional telephones. Because of the development of information technology, smartphones are not only limited as a tool to communicate both verbally and in writing but also as a medium to access various information and even as a means to do online transactions through various e-commerce platforms that can be installed on smartphones. Technological advances are also rapidly replacing books, newspapers, and other printed sources of 
information with digital-based ones. The development of information and technology ultimately affects people's lives.

Every individual wants the convenience of doing various things. No exception in obtaining public services, technological developments have changed people's perceptions of public services that are increasingly fast, transparent, and easily accessible (Mergel et al., 2019). People expect the services provided by the government to be at least equivalent to the services they receive when transacting online with private parties (Benjamin \& Potts, 2018). As an institution in charge of providing services to the community, the government has a great responsibility to meet the expectations of the community. Dramatic changes must be made to give birth to public service innovations that are able to provide fast, easy, and quality services to the community. In order to achieve this, the government changed its operating model to be more effective and efficient by transforming public services into digital-based ones. The application of technology, information, and communication in government as well as the enormous digital influence in society will be able to create a more efficient, effective, and transparent government (Gil-garcia et al., 2017).

Digital transformation is related to the use of technology, information and communication to create new foundations and capabilities in business activities, the public sector, and human life that can significantly improve performance (Martin, 2008). In the context of governance, digital transformation also includes efforts to be able to integrate services so as to increase added value and community satisfaction as service users. Not only focusing on information systems and technology factors but also digital transformation as a work method is also fully supported by the reliability of technology (Benjamin \& Potts, 2018). Digital transformation is a must for public institutions in facing a digital era that is full of disruption and challenges of very fast data development. Public institutions are required to be able to quickly adapt to changes that occur in the digital transformation program carried out.

As a large country consisting of thousands of islands, digital transformation in Indonesia plays an important role in creating national connectivity in addition to the physical infrastructure development that has been carried out to make Indonesia advanced. This is as stated by the President of the Republic of Indonesia, Joko Widodo that: 
“Digital transformation is a quick and strategic solution to bring Indonesia into the

future. However, it is also very important to continue to create digital sovereignty and independence" (Presidenri.go.id, 2021)

This means that digital transformation is an important factor that is indispensable for the future of the nation. Digitalization will further accelerate programs and policies that will be carried out by the government in an effective and efficient manner. In relation to public services, digital transformation is carried out to provide public services that are able to adapt and meet the expectations of the community (Menpan.go.id, 2021).

As a manifestation of the government's commitment to realizing digital transformation in public services, the government has set presidential regulation no. 95 of 2018 concerning Electronic-Based Government Systems to realize quality public services and clean, effective, transparent and accountable electronic-based governance. However, in its development, the implementation of SPBE implementation still needs to be further improved. Based on a survey conducted by the United Nations in 2020, the implementation of SPBE in Indonesia is still ranked 88th out of 193 countries. This indicates that Indonesia is still far behind other countries (djkn.kemenkeu.go.id, 2020).

The application of digital transformation has been practised in Ministries/Agencies, one of which is the Ministry of Finance. As an institution that is responsible for managing state finances with stakeholders covering all regions of Indonesia, digital transformation is a necessity that must be carried out to be able to accelerate quality, effective, efficient, transparent and accountable public services. Since 2019, the Ministry of Finance has included a digital transformation program in the strategic initiatives of Bureaucratic Reform and Institutional Transformation. In supporting the digital transformation program in the internal environment, the Ministry of Finance has compiled four strategic initiatives, namely strengthening organizational culture: New Thinking of Working; implementation of Office Automation in order to build a Digital Workplace; HR Development; and Modern use of elearning as the main tool for human resource development (KMK.302/KMK01/2019). In addition, services to external stakeholders have also been changed in the form of digital services that allow service delivery without being physically present (directly) at the Ministry of Finance office (Kemenkeu.go.id, 2020). 
The digital transformation program is also a program to respond to the needs of the community and stakeholders who are increasingly accustomed to the use of technology and the expectations of the Ministry of Finance's employee needs which have changed greatly because almost $70 \%$ of employees are millennials who are already digital natives (Kemenkeu.go.id, 2020). According to the Minister of Finance, Sri Mulyani, the Ministry of Finance has carried out a series of transformation programs since before the pandemic, including digitizing documents, official documents, digital signs, and flexible working (Sindonews, 2020). However, the digital transformation program is still in its infancy. The Covid-19 pandemic has accelerated digital transformation efforts. The existence of social restrictions that change various aspects of life, giving rise to new habits or new normal demands transformation efforts. The development of digital transformation at the Ministry of Finance is increasingly rapid when there is a Covid-19 pandemic in 2020 which causes changes in work mechanisms due to social restrictions to prevent transmission of Covid-19. 19 in the office environment. The suggestion to work from home (Working From Home) makes the use of technology a necessity to keep working smoothly with optimal performance.

The digital transformation program that has been carried out has been able to support the smooth implementation of the duties of employees and institutions during the Covid-19 pandemic. Vice Minister of Finance, Suahasil Nazara stated that 90\% of Ministry of Finance employees feel that the work they do online can still run effectively. The success of implementing the Ministry of Finance's digital transformation is certainly strongly influenced by various factors. It is important to know the various factors that support the successful implementation of digital transformation in the hope that it can be applied to other public institutions that are in the process of digital transformation. Therefore, the focus of this article is to find out the research question about the supporting factors for the digital transformation program at the Ministry of Finance.

\section{Methods}

This study uses a descriptive research method with a qualitative approach. According to Moleong (2014), a qualitative approach produces descriptive data in the form of words or writings from people and observed behaviour. In this study, researchers used a qualitative approach to obtain an overview of the digital transformation carried out by the Ministry of 
Finance and the factors that support the transformation program. The data used is secondary data obtained from a literature study. In this study, data and information related to digital transformation at the Ministry of Finance were collected from various sources such as books, journals, reports, and information from the Ministry of Finance's official website. Various data that have been collected including the results of interviews with Ministry of Finance informants that have been published in the form of reports are then analyzed using theory and concluded.

\section{Results and Discussion}

Laseau (1980: 120) in Najoan and Johansen (2012) means that transformation is a process of change that takes place continuously until it reaches the final stage, change is a response made to internal and external influences. Concerning the organization, transformation is a process of change carried out by the organization to adapt to the external environment and integrate it into the organization by empowering its resources. Environmental conditions with very fast and complex dynamics of change require organizations to be able to adapt so as not to be left behind by the times. The organizational transformation aims to improve organizational capabilities in responding to the challenges of a rapidly changing environment. Likewise, with the public sector, transformation is a must to respond to various challenges and changes that occur to deliver services that meet public expectations effectively and efficiently while still implementing transparency and accountability.

Digital transformation is related to the use of technology, information and communication to create new foundations and capabilities in business activities, the public sector, and human life that can significantly improve performance (Martin, 2008). According to Westerman et al (2011), digital transformation is the use of technology to improve organizational performance. Another opinion says that digitalization is an important improvement in public sector organizations to be more effective and efficient in achieving output but not only limited to available technological advances (Alford \& Flynn, 2009). Information technology is a key factor in determining the success of digital transformation, but a fundamental commitment is needed to improve processes, policies and leadership (Mergel et al., 2019). 
In responding to the times with the rapid development of technology and information, Transformation is a necessity that must be carried out by public sector organizations. As an institution that has a central role in the administration of government, the Ministry of Finance always strives to improve the system and organizational culture so that it can always adapt to changes so that it can provide optimal services. The Ministry of Finance has begun to integrate aspects of digitalization into its transformation initiatives. The Ministry of Finance's digital transformation is carried out to realize service improvements that focus on the community and stakeholders (citizen-centric); improve the efficiency of business processes and operations; improve service quality through digitization; build a data-driven organization for more efficient policy formulation; encourage a collaborative and digitized work culture, and increase collaboration with other Ministries and Institutions, to enhance the reputation of the Ministry of Finance as a modern world-class institution (Kemenkeu.go.id, 2020)

As a basis for implementing digital transformation, through the Minister of Finance Decree No. 302/KMK01/2019 concerning Implementation of Strategic Initiatives and Institutional Transformation, the Ministry of Finance has compiled four strategic initiatives that become the central theme in the transformation process, namely strengthening organizational culture: New Thinking of Working; implementation of Office Automation to build a Digital Workplace; HR Development; and Modern use of e-learning as the main tool for human resource development. These four central themes underlie the digital transformation program at the Ministry of Finance. The various digital transformation programs carried out have also had a major impact on the smooth implementation of work during the Covid-19 pandemic. The digital transformation program that has been launched and is part of the strategic initiative in Bureaucratic Reform and Institutional Transformation (RBTK) in 2019 has become very applicable and relevant to the new normal concept during the Covid-19 pandemic which requires changing mechanisms in working by utilizing technology. The digital transformation carried out by the Ministry of Finance has also received appreciation from the Ministry of PAN-RB with the highest score for an electronic-based government system (Buletin Kinerja, 2019)

The success of implementing digital transformation in the Ministry of Finance is influenced by various factors. The factors that support the digital transformation program at 
the Ministry of Finance when viewed from the perspective of Osmundsen (2018) are presented in the following table.

\section{Table 1.}

\section{Supporting Factors for Ministry of Finance's Digital Transformation}

\begin{tabular}{|c|c|c|}
\hline No. & Criteria & Implication \\
\hline 1. & $\begin{array}{l}\text { Supportive and agile } \\
\text { organizational culture }\end{array}$ & $\begin{array}{l}\text { - Leadership } \\
\text { - Organizational culture that is open to change } \\
\text { - Implementation of New Thinking of Working (NTOW) } \\
\text { through Flexible Working Hour (FWH), Flexible Working } \\
\text { Space (FWS) including Remote Working }\end{array}$ \\
\hline 2. & $\begin{array}{l}\text { Well-managed } \\
\text { transformation activities }\end{array}$ & $\begin{array}{l}\text { - IT and HR infrastructure } \\
\text { - HR training and development through e-learning }\end{array}$ \\
\hline 3. & Leverage Knowledge & - Benchmarking \\
\hline 4. & $\begin{array}{l}\text { Engage Managers and } \\
\text { Employees }\end{array}$ & - Change Management Program \\
\hline 5. & $\begin{array}{l}\text { Develop a digital business } \\
\text { strategy and align business } \\
\text { and IS }\end{array}$ & - Digital Workplace and Office Automation \\
\hline
\end{tabular}

Source: the results of the author's data processing based on the perspective of Osmunsend (2018)

Based on the table 1, it can be seen that several aspects support the digital transformation program at the Ministry of Finance, including:

1. Supportive and agile organizational culture

One of the most important things in realizing a digital transformation program is the existence of a supportive organizational culture to be able to adapt to the changes made. Digital transformation requires significant changes through an organizational strategy which may be difficult to carry out without drastic changes in organizational systems and culture (Kotey \& Sharma, 2015). These efforts require the full support of creative leaders and have the ability to make decisions that have a significant impact (Sow \& Aborbie, 2018). Thus, the leadership aspect is important in encouraging the transformation process and strengthening organizational culture. As a manifestation of the leadership's commitment, the Minister of Finance, Deputy Minister of Finance, and all Echelon I Unit Leaders at the Ministry of Finance have held a series of strategic meetings in the Leaders Offsite Meeting (LOM) forum on 15-18 December 2018 to strengthen the digital vision in the organizational transformation of the Ministry of Finance. . Furthermore, the LOM results were reviewed again by the Echelon I unit leaders and discussed again in the RBTK Steering Committee Meeting (SCM) forum on January 31, 2019. The LOM and SCM results were followed up by setting 
KMK/302/KMK.01/2019 as guidelines for implementing digital transformation Ministry of Finance as the focus of RBTK (Kemenkeu.go.id, 2019).

Organizational culture is an important aspect in supporting the changes made. Therefore, organizational culture is needed that can provide convenience and facilitate the transformation program carried out. To achieve this, the Ministry of Finance has incorporated the New Thinking of Working (NTOW) concept as a new paradigm and work mechanism that can be carried out by employees. NTOW aims to create an adaptive, digital-based work culture, by upholding integrity to increase the productivity and performance of the Ministry of Finance. Sudarto, Assistant of Minister for Organization, Bureaucracy, and Technology (OBTI) Ministry of Finance in Financial Media said that:

"This is a concept where we will be more flexible regarding the time, place and space to work and with the support of information technology. The hope is, delivering results according to the expectations of our stakeholders or following the vision and mission of the ministry of finance" (Media Finance, 2020)

This means that NTOW is the development of a new culture and mechanism in working by utilizing information technology. Through this concept, Ministry of Finance employees are expected to remain productive in their work without being limited by space and time. The efforts made in NTOW are by establishing a Flexible Working Hour (FWH) policy, Flexible Working Space (FWS) including remote working to encourage the achievement of work-life balance, increase work productivity, and bureaucratic efficiency (LAP PMO SJ, 2019).

2. Well-managed transformation activities

According to Berghaus and Back (2017) activities before and during transformation are important. The transformation process is not something that can be done instantly but requires preparation and integrated efforts that require support from all organizational components. One of the important activities is to always increase digital capacity by managing the initiation and simplification of processes and infrastructure updates. This is also done by the Ministry of Finance in overseeing the digital transformation program carried out, namely by preparing basic infrastructure and IT human resources which are the main supports in digital transformation. This is as conveyed by Sudarto, Assistant of Minister for Organization, Bureaucracy, and Technology (OBTI), Ministry of Finance: 
“The IT infrastructure aspect is like a table stake in a poker game, which is something that must be owned before playing" (Buletin Kinerja, 2019)

This means that before carrying out digital transformation, the Ministry of Finance has built IT infrastructure including its human resources as the main capital in implementing the digital transformation program. This was also emphasized by Herry Siswanto, Head of the Financial Technology and Information System Center of the Ministry of Finance, who said that:

“....aspects of data centre (DC) technology. With an area of around $900 \mathrm{~m} 2$, the Ministry of Finance DC has a very sufficient capacity in managing system operations to support the Ministry of Finance's business processes," he said optimistically. The Ministry of Finance DC is also supported by the Data Recovery Center (DRC) as redundancy for disaster recovery" (Media Finance, 2020)

This means that in supporting business processes in digital transformation, the Ministry of Finance has prepared IT infrastructure that can accommodate the needs of digital services and ensure data security in the event of a disruption.

In addition, to prepare human resources capable of adapting to technological developments, the Head of the Ministry of Finance's HR Bureau, Humaniati emphasized the importance of implementing three aspects, namely organization and culture, strengthening human resources, and regulations (Media Finance, 2020). From the organizational and cultural aspects, by cultivating a technology-based organizational environment and culture so that employees become familiar with the use of technology. In addition, when viewed from the HR side, based on the Ministry of Finance's HR Bureau, the total number of employees as of September 2021 is 80,506 employees with a composition based on generation as shown in graph 1 below. 


\section{Graph 1.}

\section{Employee Composition by Generation}

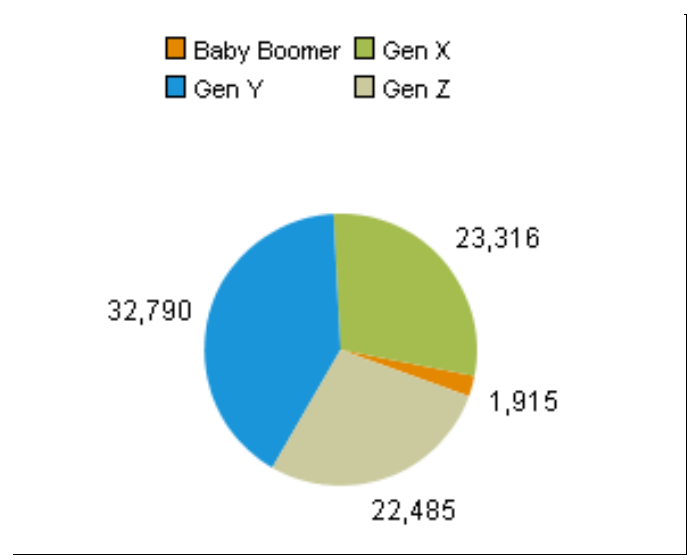

Source: Ministry of Finance HR Bureau, 2021

Based on graph 1, it is known that the Ministry of Finance employees consist of the baby boomer generation (1946-1960), generation X (1961-1980), generation Y (19811994), and generation $Z$ (> 1995). Ministry of Finance employees are dominated by Generation $\mathrm{Y}$ and $\mathrm{Z}$ with a total of $68.7 \%$, followed by Generation $X$ at $28.9 \%$ and the baby boomer generation at $2.4 \%$. Generation $\mathrm{Y}$ is a generation that was born during a transitional period of technological development, while Generation $\mathrm{Z}$ was born in an era of technological development (Dadvari \& Do, 2019). Thus, both generations thrive in an environment that is already familiar with the use of technology. This allows Ministry of Finance employees, who are dominated by both generations, to quickly adapt to various changes resulting from digital transformation.

In addition, to improve employee competencies, HR strengthening programs are carried out by developing hard competencies and soft competencies through digitalbased learning media (e-learning) implemented by the Finance Education and Training Agency (BPK) of the Ministry of Finance. Lastly, regulatory strengthening is carried out to harmonize the implementation of the use of technology in all units of the Ministry of Finance. (Financial Media, 2020).

3. Leverage knowledge

According to Osmundsen (2018), increasing internal and external knowledge is very important in digital transformation. External studies play a very important role in improving the quality of digital products and services. In addition, digital transformation that focuses on the internal environment will be able to encourage employees to use 
technology to be more innovative in carrying out their work (Mueller and Renken, 2017). To support the Ministry of Finance's digital transformation, comparative studies and benchmarking to external parties were carried out to dig deeper information about best practices and important knowledge as capital in the transformation process. This is in line with what was conveyed by the Secretary General of the Ministry of Finance, Hadiyanto who said that:

"To be able to play an optimal role, the Ministry of Finance increases the capacity of employees in the field of digital transformation by providing education and training to employees who are directly involved in digital transformation efforts" (Mix.co.id, 2018)

In line with the opinion of the Secretary General of the Ministry of Finance, as an effort to increase employee knowledge and competence in the field of digital transformation, in 2018 the Ministry of Finance in collaboration with the Rajawali Foundation has sent 18 selected employees to take part in the non-degree executive education program “Digital Transformation in Government: Innovating Public Policy and Services" at Harvard Kennedy School, United States. (Mix.co.id, 2018). In addition, in developing the concept of FWS as a new culture at work (NTOW), to determine the success of the implementation of FWS which has previously been applied to private institutions, the Ministry of Finance has carried out benchmarking to several private offices, such as PT. Unilever Indonesia Tbk, PT. Telkom Tbk, and PT. Bank DBS Indonesia (SJ PMO LAP, 2019).

4. Engage managers and employees

HR capital from the organization has an important role in the process and impact resulting from the digital transformation carried out. Therefore, it is important to be able to involve employees in various aspects of the digital transformation process carried out. In the digital transformation process at the Ministry of Finance, the program carried out to involve employee participation and as a means to increase employee understanding of change so that in the end it will create employee engagement with change is Change Management (CM). Some of the stages in $\mathrm{CM}$ include:

a. Inform, to provide understanding to every employee regarding the transformation program carried out 
b. Support, to provide support for the implementation of the transformation

c. Excite, to attract employees to transformation

d. Enable, to provide opportunities for employees to be actively involved in the transformation process.

Several activities were carried out such as the transformation ambassador program which involved 945 employees consisting of 206 Echelon III officials as change agents and 739 Echelon IV officials and implementers as the lighthouse team. In addition, other forms of activity are holding transformation talks, Focus Group Discussions (FGD), and Sharing Sessions on transformation programs to various agencies (LAP CTO, 2019).

5. Develop a digital business strategy and align business and IS

According to (Nsights et al., 2013), digital business strategy is an organizational strategy that is prepared and implemented by utilizing digital resources to create value differences. In implementing digital transformation at the Ministry of Finance, changes in business processes are carried out by integrating administrative activities in an Office Automation (OA) system. $\mathrm{OA}$ is the digitization of office administration business processes towards a digital workplace. OA is a process of digitizing general organizational activities (such as archives, staffing, assets), and collaboration/communication (mail, electronic mail, chat, video conferencing) carried out by all employees through simplification and interoperability of business processes using the concept of sharing with others. utilizing technology and information systems to improve quality, productivity, and work efficiency as well as support the realization of a green organization. (SJ PMO LAP, 2019)

Based on the five aspects of supporting the Ministry of Finance's digital transformation from the perspective of Odmunsen, it is known that the implementation of digital transformation requires full support and commitment from the leadership to prepare various resources and systems that can support the digital transformation program launched. The change from conventional work mechanisms to digital-based is supported by the internalization of organizational culture that can create an adaptive digital work environment. 


\section{Conclusion}

The development of technology and information has also changed people's perceptions of public services. Public services are expected to be faster and easier to access using digital technology. Therefore, digital transformation is an effort that must be made to provide services that are following the wishes of the community. The Ministry of Finance is one of the public institutions that has been able to implement a digital transformation program. Various factors supporting the digital transformation program at the Ministry of Finance can be viewed from 5 aspects, the first aspect is a supportive and agile organizational culture, this aspect is related to the commitment and full support of the leadership at the Ministry of Finance to create a digital work system and build an organizational culture that supports change; the second aspect is well-managed transformation activities, this aspect is related to the preparation of infrastructure resources, human resources and regulations as capital in building and maintaining the continuity of the transformation program; the third aspect is leverage knowledge, this aspect relates to increasing the capacity of the Ministry of Finance employees and organizational readiness in realizing digital transformation programs through various benchmarking activities; the fourth aspect is engaging managers and employees, this aspect is related to the Ministry of Finance's efforts to build a sense of belonging among employees by developing a Change Management (CM) program; the fifth aspect is developing a digital business strategy, this aspect is related to the steps of the Ministry of Finance in building a digital office through the automation of various services and work administration through the Office Automation (OA) platform.

Various factors supporting the success of the digital transformation program at the Ministry of Finance can be used as additional references to support the implementation of digital transformation programs in other institutions. The more government institutions that implement digital transformation will be able to realize a clean, transparent, and accountable government and improve services to the community. However, this research only focuses on the factors that support the digital transformation program at the Ministry of Finance. Therefore, to find a more comprehensive related to digital transformation, further research can discuss implementation studies and the impact of implementing digital transformation for organizations, employees, and the community as recipients of public services. 


\section{References}

Alford, J., \& Flynn, J. O. (2009). Making Sense of Public Value: Concepts , Critiques and Emergent Meanings. 171-191. https://doi.org/10.1080/01900690902732731

Benjamin, K., \& Potts, H. W. (2018). Digital transformation in government: Lessons for digital health? Digital Health, 4, 205520761875916. https://doi.org/10.1177/2055207618759168

Chi, M., Zhao, J., George, J. F., Li, Y., \& Zhai, S. (2017). The influence of inter-firm IT governance strategies on relational performance: The moderation effect of information technology ambidexterity. International Journal of Information Management, 37(2), 43-53. https://doi.org/10.1016/j.ijinfomgt.2016.11.007

Dadvari, A., \& Do, B. (2019). Modeling Gen Z Continuance Intention toward Ubiquitous Media System: Applying Technology Readiness and Technology Acceptance Model. 30, 37-56. https://doi.org/10.6186/IJIMS.201903

Gil-garcia, J. R., Dawes, S. S., Pardo, T. A., Dawes, S. S., \& Digital, T. A. P. (2017). Digital government and public management research: finding the crossroads. Public Management Review, 00(00), 1-14. https://doi.org/10.1080/14719037.2017.1327181

Kotey, B., \& Sharma, B. (2015). Predictors of flexible working arrangement provision in small and medium enterprises ( SMEs ). 5192(December). https://doi.org/10.1080/09585192.2015.1102160

Mergel, I., Edelmann, N., \& Haug, N. (2019). Defining digital transformation: Results from expert interviews. Government Information Quarterly, 36(4), 101385. https://doi.org/10.1016/j.giq.2019.06.002

Nsights, G. E. O. F. I., Sawy, O. A. El, \& Pavlou, P. A. (2013). D IGITAL B USINESS S TRATEGY: T OWARD A N EXT. 37(2), 471-482.

Sow, M., \& Aborbie, S. (2018). Impact of Leadership on Digital Transformation. Business and Economic Research, 8(3), 139. https://doi.org/10.5296/ber.v8i3.13368

Martin, A. (2008). Digital Literacy and the "Digital Society". In C. Lankshear, \& M. Knobel (Eds.), Digital Literacies: Concepts, Policies, and Practices (pp. 151-176). New York: Peter Lang

Mergel, I., Edelmann, N., \& Haug, N. (2019). Defining digital transformation: Results from expert interviews. Government Information Quarterly, 36(4), 101385. https://doi.org/10.1016/j.giq.2019.06.002 
Minister of Finance's Decree No. 302/KMK01/2019. Concerning the Implementation of the Strategic Initiatives for the Bureaucratic Reform and Institutional Transformation Program.

Ministry of Finance. (2019). Mengawal Perubahan. Buletin Kinerja. Jakarta. Edisi XXXIX/Semester I 2019

Moleong, J.Lexy. (2014). Metodologi Penelitian Kualitatif. Bandung, Indonesia: Remaja Rosda Karya

Mueller, B., \& Renken, U. (2017). Helping Employees to be Digital Transformers - the Olympus .connect Case. In ICIS 2017 Proceedings (pp. 1-19). Retrieved from https://aisel.aisnet.org/icis2017/

Najoan, Stephanie Jill dan Johansen Mandey. 2011. Transformasi Sebagai Strategi Desain. Media Matrasain, 8(2):117-130

Nsights, G. E. O. F. I., Sawy, O. A. El, \& Pavlou, P. A. (2013). Digital Business S Trategy: Toward A Next.37(2), 471-482. Retrieved from https://papers.ssrn.com/

Osmundsen, Karen; Iden, Jon; and Bygstad, Bendik, "Digital Transformation: Drivers, Success Factors, and Implications" (2018). MCIS 2018 Proceedings. 37. Retrieved from https://aisel.aisnet.org/mcis2018/37

Project Management Office (PMO). (2019). Report of the Secretariat General of the Ministry of Finance for 2019

Setiawan. (2018, September 7). Pegawai Kemenkeu Ikuti Pelatihan Transformasi Digital di Harvard. Retrieved from https://mix.co.id/marcomm/news-trend/pegawaikemenkeu-ikuti-pelatihan-transformasi-digital-di-harvard/

Sow, M., \& Aborbie, S. (2018). Impact of Leadership on Digital Transformation. Business and Economic Research, 8(3), 139. https://doi.org/10.5296/ber.v8i3.13368 